\title{
Types and Scales of Enterprises Being Run by the Women Entrepreneurs of Self-help Groups in Andhra Pradesh
}

\author{
Siddeswari, G.K." ${ }^{1}$, Sathya Gopal, P.V. ${ }^{2}$, Sailaja, V. ${ }^{1}$ and Ravindra Reddy, B. ${ }^{3}$ \\ ${ }^{1}$ Department of Agricultural Extension, S.V. Agricultural College, Tirupati-517 502, India \\ ${ }^{2}$ Department of Agricultural Extension, Agricultural College, Bapatla-522101, India \\ ${ }^{3}$ Department of Statistics and Computer Applications, S.V. Agricultural College, Tirupati-517 502, India \\ *Corresponding author: siddu.gk18@gmail.com (ORCID ID: 0000-0001-8938-2516)
}

Received: $19-08-2019$

Revised: 14-01-2020

Accepted: 29-02-2020

\begin{abstract}
The present investigation was carried out in three districts of Andhra Pradesh viz., Chittoor (from Rayalaseema region), East Godavari (from Coastal region) and Srikakulam (from North Coastal region) during 2016-18. About 63 types of enterprises being run by 240 entrepreneurs depending upon availability of natural resources and demand in the local area coming to a total of 286 enterprises. Provision shop $(16.08 \%)$ was the main choice of the respondents, followed by Tailoring (13.29\%), Dairy (6.99\%), equal $(4.55 \%)$ percentage with Small hotel/Tiffin centre and Sarees and dress materials/ Cloth business and Fancy shop (4.20\%). One-third (33.22\%) of the SHG members running the enterprise with an income range of ₹ 50,001-1,00,000. Only 0.70 per cent of the SHG members running the enterprise with an income range of ₹ 5,00,001 and above. More than half (56.99\%) of the enterprises being run by the SHG women entrepreneurs were the primary sources of income for their family. There was a significant association between the types of enterprises and scale of enterprise.

\section{Highlights}

(0 The findings of the study revealed that majority of women were found to be involved in traditional activities as they were less risky. Hence, training on viable and challenging enterprises should be given to these groups thus decreasing competition in the market.
\end{abstract}

Keywords: Annual income, scale of enterprise, women entrepreneurs, self-employment, training programmes

'Woman' is the key for success of any human being because of their excellent qualities such as hard-working nature, patience, cordial affiliation, convincing capacity, communication etc., in handling multifaceted activities. On the other hand women in rural areas are comparatively less educated, economically poor, confined to limited geographical boundaries and live under rigid structural constraints. Entrepreneurship is one of the prospective options to uplift rural women by generating self-employment opportunities. The concept of Self Help Group (SHG) acts as a driving force for the rural women with the ultimate objective of converting household women as enterprising women and encouraging them to enter into entrepreneurial activities. SHGs are the main medium for rural employment generation. Encouragement and support will solve the problems of rural women, which can be achieved by realizing the need for empowerment through SHGs. Since the overall empowerment of women is crucially dependent on economic empowerment, these SHGs could generate income and employment to build their empowerment (Sowjanya, 2007). Exploration of different types and scales of enterprises being run by

How to cite this article: Siddeswari, G.K., Sathya Gopal, P.V., Sailaja, V. and Ravindra Reddy, B. (2020). Types and scales of enterprises being run by the women entrepreneurs of self-help groups in Andhra Pradesh. Economic Affairs, 65(1): 57-62. 
AESSRA

the women entrepreneurs was useful for identifying the area specific enterprises being run by the respondents, need to conduct training programmes to change the attitude of women entrepreneurs to take up skill oriented and innovative enterprises which were based on availability of natural resources and demand in the local area and also need for conversion of all entrepreneurs as largescale entrepreneurs.

\section{METHODOLOGY}

Andhra Pradesh state was purposively selected. One district each from three regions of the state viz., Chittoor (from Rayalaseema region), East Godavari (from Coastal region) and Srikakulam (from North Coastal region) were purposively selected based on the highest number of SHGs. Four mandals from each district, two villages from each mandal and one hamlet from each village were purposively selected based on the highest number of SHGs thus making a total of 12 mandals, 24 villages and 24 hamlets respectively. From each village ten women entrepreneurs were selected from all the existing SHGs in that hamlet, by using simple random sampling procedure thus making a total of 240 women entrepreneurs as the sample of the study. In the present study an attempt was made to find out the different enterprises being run by the women entrepreneurs and annual income generated from these enterprise and contribution of enterprise income to the family income were analysed. Cross tabs were used where ever it is necessary.

\section{Chi-square test for Independence of Attributes $\left(\chi^{2}\right)$}

Chi square is a statistical test used to test the association between two categorical variables. The Chi-square statistic $(\chi 2)$ used for the study was under,

$$
\chi^{2}=\sum_{i=1}^{n} \frac{\left(O_{i}-E_{i}\right)^{2}}{E_{i}}
$$

where,

$$
\begin{aligned}
& O_{i}=\text { Observed frequencies } \\
& E_{i}=\text { Expected frequencies } \\
& n=\text { Number of cells (or classes) }
\end{aligned}
$$

\section{RESULTS AND DISCUSSION}

It is very important to examine the types of the enterprises being run by the respondents, the scales of enterprises and their contribution to the annual income of the family.

\section{Number of Enterprises being run by the Women Entrepreneurs}

From the table 1 it could be concluded that majority $(83.33 \%)$ of the respondents have established single enterprise followed by two enterprises $(15.00 \%)$, three enterprises $(1.25 \%)$ and only 0.42 per cent of the respondents have established five enterprises and coming to a total of 286 enterprises.

Table 1: Number of enterprises being run by the women entrepreneurs $(n=240)$

\begin{tabular}{lllll}
\hline \begin{tabular}{l} 
Number of $\begin{array}{c}\text { sumprises } \\
\text { enterpristished } \\
\text { establish }\end{array}$ \\
\cline { 2 - 5 }
\end{tabular} & $\begin{array}{c}\text { Number of } \\
\text { entrepreneurs }\end{array}$ & \multicolumn{2}{c}{$\begin{array}{c}\text { Total number of } \\
\text { enterprises }\end{array}$} \\
\hline Frequency Percent- & $\begin{array}{c}\text { Frequency } \\
\text { age }\end{array}$ & $\begin{array}{l}\text { Percent- } \\
\text { age }\end{array}$ \\
Two & 200 & 83.33 & 200 & 69.93 \\
Three & 36 & 15.00 & 72 & 25.17 \\
Five & 3 & 1.25 & 9 & 3.15 \\
\hline Total & 1 & 0.42 & 5 & 1.75 \\
\hline
\end{tabular}

\section{Types of Enterprises being run by the Women Entrepreneurs}

In the present study, an attempt was made to find out the enterprises owned by members of SHGs. The respondents were asked open-ended questions to enlist the income generative activities carried out by members of SHGs.

Table 2: Types of enterprises being run by the women entrepreneurs $(n=240)$

\begin{tabular}{llllll}
\hline $\begin{array}{l}\text { S1. } \\
\text { No. }\end{array}$ & Enterprise & $\begin{array}{l}\text { Rayala- } \\
\text { seema }\end{array}$ & Coastal & $\begin{array}{l}\text { North- } \\
\text { Coastal }\end{array}$ & Total \\
\hline 1 & Provision shop & 12 & 19 & 15 & $46(16.08)$ \\
2 & Tailoring & 14 & 17 & 7 & $38(13.29)$ \\
3 & Dairy & 13 & 3 & 4 & $20(6.99)$ \\
4 & Fancy shop & 4 & 6 & 2 & $12(4.20)$ \\
5 & $\begin{array}{l}\text { Small hotel/ } \\
\text { Tiffin centre }\end{array}$ & 7 & 3 & 3 & $13(4.55)$ \\
6 & $\begin{array}{l}\text { Sarees and } \\
\text { dress materials/ }\end{array}$ & 6 & 2 & 5 & $13(4.55)$ \\
& $\begin{array}{l}\text { Cloth business } \\
7\end{array}$ & & & & \\
Petty shop & 1 & 1 & 8 & $10(3.50)$
\end{tabular}




\begin{tabular}{|c|c|c|c|c|c|}
\hline 8 & Floor mill & 4 & 1 & 3 & $8(2.80)$ \\
\hline 9 & Fruit business & 2 & 1 & 5 & $8(2.80)$ \\
\hline 10 & Pottery making & 1 & 6 & - & $7(2.45)$ \\
\hline$\frac{1}{1}$ & Fish selling & - & 6 & - & $6(2.10)$ \\
\hline 12 & $\begin{array}{l}\text { Vegetable } \\
\text { selling }\end{array}$ & - & 2 & 4 & $6(2.10)$ \\
\hline & Bangle shop & - & - & 6 & $6(2.10)$ \\
\hline 14 & Water plant & 2 & 1 & 2 & $5(1.75)$ \\
\hline 15 & Laundry shop & 1 & 4 & - & $5(1.75)$ \\
\hline 16 & $\begin{array}{l}\text { Sweet shop/ } \\
\text { Bakery shop }\end{array}$ & 1 & - & 3 & $4(1.40)$ \\
\hline 17 & Weaving & - & - & 4 & $4(1.40)$ \\
\hline 18 & Beauty parlour & 3 & - & - & $3(1.05)$ \\
\hline 19 & Flower vending & 2 & - & 1 & $3(1.05)$ \\
\hline 20 & $\begin{array}{l}\text { Dairy products } \\
\text { shop }\end{array}$ & 1 & 2 & - & $3(1.05)$ \\
\hline 21 & Pooja items & 1 & - & 2 & $3(1.05)$ \\
\hline 22 & Basketry shop & - & 3 & - & $3(1.05)$ \\
\hline 23 & $\begin{array}{l}\text { Thread } \\
\text { bangles } \\
\text { and earring } \\
\text { making }\end{array}$ & - & 1 & 2 & $3(1.05)$ \\
\hline 24 & Noodles shop & - & - & 3 & $3(1.05)$ \\
\hline 25 & Tea house & - & - & 3 & $3(1.05)$ \\
\hline 26 & $\begin{array}{l}\text { Goatery/ } \\
\text { Shepary }\end{array}$ & - & - & 3 & $3(1.05)$ \\
\hline 27 & $\begin{array}{l}\text { Threads } \\
\text { business }\end{array}$ & 2 & - & - & $2(0.70)$ \\
\hline 28 & $\begin{array}{l}\text { Spinning top } \\
\text { business }\end{array}$ & 2 & - & - & $2(0.70)$ \\
\hline 29 & Juice shop & 1 & 1 & - & $2(0.70)$ \\
\hline 30 & $\begin{array}{l}\text { Soft drink } \\
\text { shop }\end{array}$ & 1 & - & 1 & $2(0.70)$ \\
\hline 31 & $\begin{array}{l}\text { Panipuri } \\
\text { business }\end{array}$ & 1 & - & 1 & $2(0.70)$ \\
\hline 32 & $\begin{array}{l}\text { Print and } \\
\text { Xerox shop/ } \\
\text { Stationary }\end{array}$ & 1 & - & 1 & $2(0.70)$ \\
\hline 33 & $\begin{array}{l}\text { Cashew } \\
\text { processing } \\
\text { unit }\end{array}$ & - & 2 & - & $2(0.70)$ \\
\hline 34 & $\begin{array}{l}\text { Paper plate } \\
\text { making }\end{array}$ & - & 2 & - & $2(0.70)$ \\
\hline 35 & Rice vending & - & 1 & 1 & $2(0.70)$ \\
\hline 36 & Handicrafts & - & 1 & 1 & $2(0.70)$ \\
\hline 37 & Pan shop & - & - & 2 & $2(0.70)$ \\
\hline 38 & Chicken shop & 1 & - & - & $1(0.35)$ \\
\hline 39 & $\begin{array}{l}\text { Mulbery/ } \\
\text { Sericulture }\end{array}$ & 1 & - & - & $1(0.35)$ \\
\hline
\end{tabular}

\begin{tabular}{|c|c|c|c|c|c|}
\hline 40 & $\begin{array}{l}\text { Groundnut } \\
\text { business }\end{array}$ & 1 & - & - & $1(0.35)$ \\
\hline 41 & $\begin{array}{l}\text { Cattle feed } \\
\text { unit }\end{array}$ & 1 & - & - & $1(0.35)$ \\
\hline 42 & $\begin{array}{l}\text { Electrical } \\
\text { business }\end{array}$ & 1 & - & - & $1(0.35)$ \\
\hline 43 & Lime business & 1 & - & - & $1(0.35)$ \\
\hline 44 & Chips making & 1 & - & - & $1(0.35)$ \\
\hline 45 & Auto & 1 & - & - & $1(0.35)$ \\
\hline 46 & Photo studio & 1 & - & - & $1(0.35)$ \\
\hline 47 & Carpenter & 1 & - & - & $1(0.35)$ \\
\hline 48 & $\begin{array}{l}\text { Wood crafts } \\
\text { shop }\end{array}$ & 1 & - & - & $1(0.35)$ \\
\hline 49 & Doll making & 1 & - & - & $1(0.35)$ \\
\hline 50 & Pickle making & - & 1 & - & $1(0.35)$ \\
\hline 51 & $\begin{array}{l}\text { Wooden logs } \\
\text { business }\end{array}$ & - & 1 & - & $1(0.35)$ \\
\hline 52 & $\begin{array}{l}\text { Neel liquid } \\
\text { blue making }\end{array}$ & - & 1 & - & $1(0.35)$ \\
\hline 53 & $\begin{array}{l}\text { Phenyl } \\
\text { making }\end{array}$ & - & 1 & - & $1(0.35)$ \\
\hline 54 & $\begin{array}{l}\text { Steel items } \\
\text { selling }\end{array}$ & - & 1 & - & $1(0.35)$ \\
\hline 56 & $\begin{array}{l}\text { Soan papdi } \\
\text { making }\end{array}$ & - & 1 & - & $1(0.35)$ \\
\hline 57 & $\begin{array}{l}\text { Seat cover } \\
\text { making }\end{array}$ & - & 1 & - & $1(0.35)$ \\
\hline 58 & Soda shop & - & 1 & - & $1(0.35)$ \\
\hline 59 & Tobacco shop & - & 1 & - & $1(0.35)$ \\
\hline 60 & $\begin{array}{l}\text { Season } \\
\text { business }\end{array}$ & - & - & 1 & $1(0.35)$ \\
\hline 61 & Cotton wicks & - & - & 1 & $1(0.35)$ \\
\hline 62 & Coconut shop & - & - & 1 & $1(0.35)$ \\
\hline 63 & Chappal shop & - & - & 1 & $1(0.35)$ \\
\hline & $\begin{array}{l}\text { Total number } \\
\text { of enterprises }\end{array}$ & $\begin{array}{l}95 \\
(33.22)\end{array}$ & $\begin{array}{l}95 \\
(33.22)\end{array}$ & $\begin{array}{l}96 \\
(33.57)\end{array}$ & $\begin{array}{l}286 \\
(100.00)\end{array}$ \\
\hline
\end{tabular}

Figures in parentheses are percentages; ** : Significant at 0.01 level of probability.

From the above table 2. It could be concluded that 63 types of enterprises being run by 240 entrepreneurs depending upon availability of natural resources and demand in the local area coming to a total of 286 enterprises. Provision shop (16.08\%) was the main choice of the respondents, followed by Tailoring (13.29\%), Dairy (6.99\%),equal (4.55\%) percentage with Small hotel/Tiffin centre and Sarees and dress materials/ Cloth business and Fancy shop $(4.20 \%)$. 
About 3.5 percent of the SHG members were setup the enterprise like Petty shop followed by Fruit business and Floor mill $(2.80 \%)$, Pottery making $(2.45 \%)$, Fish selling, Vegetable selling and Bangle shop $(2.10 \%)$, equal $(1.75 \%)$ percentage with Laundry shop and Water plant, Sweet shop/Bakery shop and Weaving (1.40\%).

Equal $(1.05 \%)$ percentage of the respondents were engaged in businesses like Dairy products shop, Basketry shop, Thread bangles and earrings making, Beauty parlour, Pooja items, Flower vending, Noodles shop, Tea house and Goatery/Shepary.

Equal $(0.70 \%)$ percentage of the members running the enterprises like Paper plate making, Rice vending, Cashew processing unit, Juice shop, Handicrafts, Spinning top business, Print and Xerox shop/Stationary, Panipuri business, Soft drink shop, Threads business and Pan shop.

Equal (0.35\%) percentage of the SHG members setup the enterprises like Neel liquid blue making, Phenyl making, Steel items selling, Cot knitting, Soan papdi making, Seat cover making, Soda shop, Tobacco shop, Chicken shop, Pickle making, Wooden logs business, Mulbery/Sericulture, Groundnut business, Cattle food unit, Electrical business, Lime business, Chips making, Wood crafts shop, Auto, Photo studio, Carpenter, Doll making, Season business, Cotton wicks, Coconut shop and Chappal shop. The above results have shown diversity of businesses been run by the women entrepreneurs. Further it also portray the zeal and enthusiasm on part of the women entrepreneurs in exploring the possible opportunities to start the businesses.

The 'chi-square' value (216.229) and ' $p$ ' value (0.000) from the table 2 predicted that, there exists a significant association between the region and 'types of enterprises being run by the women entrepreneurs'. The finding was in agreement with finding of Hemalatha (2012), Borah (2014), Vijayabharathi and Masthani (2014)and Soni (2015).

\section{Scales of Enterprises being run by the Women Entrepreneurs}

The data in table 3 shows that the one-third (33.22\%) of the SHG members running the enterprise with an income range of ₹ 50,001 -1,00,000 followed by 30.42 per cent with $₹ 1,00,001-₹ 2,00,000,26.92$ per cent with ₹ 50,000 and below, 8.74 per cent with
₹ 2,00,001 - ₹ 5,00,000 and a tiny $(0.70 \%)$ percent with ₹ 5,00,001 and above. The 'chi-square' value (18.410) and ' $\mathrm{p}$ ' value (0.04) from the table predicted that, there exists a significant association between region and income of women entrepreneurs. The result signifies the existence of majority of cottage industries started with limited capital and earning limited profits. These results were in accordance with the findings of Bhagyasree (2014).

Table 3: Scales of enterprises being run by the women entrepreneurs $(n=240)$

\begin{tabular}{|c|c|c|c|c|}
\hline $\begin{array}{l}\text { Scale of } \\
\text { enterprise } \\
\text { (in ₹) }\end{array}$ & Rayalaseema & Coastal & $\begin{array}{l}\text { North } \\
\text { Coastal }\end{array}$ & Total \\
\hline $\begin{array}{l}50,000 \text { and } \\
\text { below }\end{array}$ & $19(6.64)$ & 32 (11.19) & $26(9.09)$ & $77(26.92)$ \\
\hline $\begin{array}{l}50,001- \\
1,00,000\end{array}$ & 35 (12.24) & $33(11.54)$ & $27(9.44)$ & $95(33.22)$ \\
\hline $\begin{array}{l}1,00,001- \\
2,00,000\end{array}$ & $28(9.79)$ & $19(6.64)$ & 40 (13.99) & $87(30.42)$ \\
\hline $\begin{array}{l}2,00,001- \\
5,00,000\end{array}$ & $12(4.20)$ & $10(3.50)$ & $3(1.05)$ & $25(8.74)$ \\
\hline $\begin{array}{l}5,00,001 \text { and } \\
\text { above }\end{array}$ & $1(0.35)$ & $1(0.35)$ & - & $2(0.70)$ \\
\hline Total & $95(33.22)$ & $95(33.22)$ & $96(33.57)$ & $286(100)$ \\
\hline$\chi^{2}=18.410^{*}$ & \multicolumn{4}{|c|}{$p=0.04$} \\
\hline
\end{tabular}

Figures in parentheses are percentages; ${ }^{* *}$ : Significant at 0.05 level of probability.

\section{Contribution of Enterprise Income to the Annual Income of the Family (in terms of sources of income)}

A look into table 4 pointed out that more than half (56.99\%) of the enterprises were the primary sources of income followed by secondary source of income $(34.97 \%)$ and tertiary source of income (6.29\%).

Table 4: Contribution of enterprise income to the annual income of the family $(n=240)$

\begin{tabular}{lllll}
\hline $\begin{array}{l}\text { Contribution } \\
\text { as source of } \\
\text { income }\end{array}$ & \multicolumn{4}{l}{ Number of entrepreneurs } \\
\cline { 2 - 5 } & Chittoor & $\begin{array}{l}\text { East } \\
\text { godavari }\end{array}$ & $\begin{array}{l}\text { Srikaku- } \\
\text { lam }\end{array}$ & Total \\
\hline $\begin{array}{l}\text { Primary } \\
\text { source }\end{array}$ & $51(17.83)$ & $48(16.78)$ & $64(22.38)$ & $\begin{array}{l}163 \\
(56.99)\end{array}$ \\
$\begin{array}{l}\text { Secondary } \\
\text { source }\end{array}$ & $38(13.29)$ & $34(11.89)$ & $28(9.79)$ & $\begin{array}{l}100 \\
(34.97)\end{array}$ \\
$\begin{array}{l}\text { Tertiary } \\
\text { source }\end{array}$ & $6(2.10)$ & $8(2.80)$ & $4(1.40)$ & $18(6.29)$ \\
$\begin{array}{l}\text { Quaternary } \\
\text { source }\end{array}$ & - & $3(1.05)$ & - & $3(1.05)$
\end{tabular}




\begin{tabular}{lllll}
$\begin{array}{l}\text { Quinary } \\
\text { source }\end{array}$ & - & $\begin{array}{l}1 \\
(0.35)\end{array}$ & - & $1(0.35)$ \\
Senary source & - & $1(0.35)$ & - & $1(0.35)$ \\
\hline Total & $95(33.22)$ & $95(33.22)$ & $96(33.57)$ & $\begin{array}{l}286 \\
(\mathbf{1 0 0})\end{array}$ \\
\hline$\chi^{2}=18.321^{\mathrm{NS}}$ & $\mathrm{p}=0.193$ &
\end{tabular}

Figures in parentheses are percentages; NS: Non significant.

The remaining meagre percent of the enterprises were under Quaternary $(1.05 \%)$ quinary $(0.35 \%)$ and senary $(0.35 \%)$ source of income. The 'chi-square' value (18.321) and ' $\mathrm{p}$ ' value (0.193) from the table 4 predicted that, the 'contribution as source of income' distribution of women entrepreneurs was not related to the region.

\section{Association between Types of Enterprises and Scales of Enterprises}

The data pertaining to the table 5 stated that,there was a significant association between type of enterprise and scale of enterprise at the 1 per cent level, since the $p$ value was less than 0.01 $(0.000<0.01)$ for the corresponding chi square value 3536.108 . Hence, it could be concluded that there was a significant association between type of enterprise and scale of enterprise.

The possible reason for the above trend might be that each enterprise will have its own quality of goods and services with differential demands and price variations. The cost incurred towards manufacturing of the goods as well as delivery of the services also might have contributed for the above trend.

Table 5: Association between types of enterprises and scales of enterprises $(n=240)$

\begin{tabular}{|c|c|c|c|c|c|c|c|}
\hline $\begin{array}{l}\dot{0} \\
\dot{z}\end{array}$ & 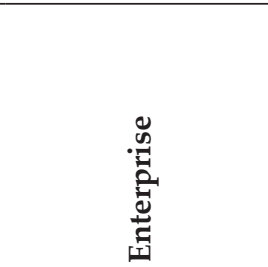 & 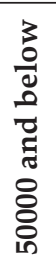 & $\begin{array}{l}8 \\
8 \\
8 \\
0 \\
0 \\
1 \\
8 \\
8 \\
0\end{array}$ & 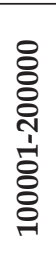 & 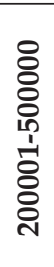 & 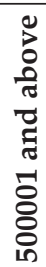 & సٓํำ \\
\hline 1 & $\begin{array}{l}\text { Paper plate } \\
\text { making }\end{array}$ & 1 & 1 & - & - & - & 2 \\
\hline 2 & Petty shop & 4 & 3 & 3 & - & - & 10 \\
\hline 3 & Provision shop & 8 & 10 & 16 & 12 & - & 46 \\
\hline 4 & Neel liquid blue & - & 1 & - & - & - & 1 \\
\hline 5 & Phenile making & - & 1 & - & - & - & 1 \\
\hline 6 & Steel items selling & 1 & - & - & - & - & 1 \\
\hline 7 & Fancy shop & 5 & 4 & 3 & - & - & 12 \\
\hline
\end{tabular}

8 Sarees and dresses $\begin{array}{lllllllll}4 & 4 & 5 & - & - & 13\end{array}$ / Cloth business

9 Laundry shop $\quad-\quad \begin{array}{lllll}4 & - & 1 & - & 5\end{array}$

10 Tailoring $\quad 9 \quad \begin{array}{llllll} & 9 & 12 & - & - & 38\end{array}$

11 Dairy $2 \begin{array}{llllll}2 & 11 & 4 & 3 & - & 20\end{array}$

12 Pottery making $\quad \begin{array}{llllllll}4 & 3 & - & - & -\end{array}$

13 Dairy products $2-1 \quad 1 \quad-\quad 3$ shop

14 Basketry shop $\quad-\quad 3 \quad-\quad-\quad-3$

15 Cot knitting $\quad 1 \quad-\begin{array}{llllll} & - & - & - & - & 1\end{array}$

16 Soan papdi $\quad-\quad-\begin{array}{llllll} & 1 & - & - & 1\end{array}$ making

17 Seat making $\quad-\quad \begin{array}{lllll} & 1 & - & - & -\end{array}$

18 Water plant $\quad-\quad-\quad \begin{array}{llllll}4 & - & 1 & 5\end{array}$

19 Rice vending $\quad-\quad 2 \quad-\quad-\quad-\quad-\quad 2$

20 Soda shop $\quad-\quad-\quad \begin{array}{lllll} & 1 & - & - & 1\end{array}$

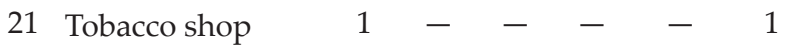

22 Small hotel/Tiffen $11 \quad 2 \quad 6 \quad 6 \quad 4 \quad-10$

23 Cashew $\quad-\quad-\quad-\quad 2 \quad-\quad 2$ processing

24 Juice shop

25 Chicken shop

26 Pickle making

27 Handicrafts

28 Thread bangles and earring making

29 Fish selling

30 Fruit business

31 Wooden logsbusiness

32 Vegetable selling $\quad-\begin{array}{lllllll}4 & 2 & - & - & 6\end{array}$

33 Floor mill $\quad 4 \quad 2 \quad \begin{array}{lllll}4 & 2 & - & 8\end{array}$

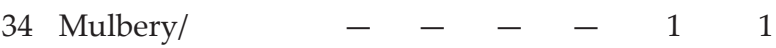
Sericulture

35 Spinning top $\quad-\quad 2 \quad-\quad-\quad-\quad$\begin{tabular}{llll}
2 \\
\hline
\end{tabular} business

36 Sweet shop/ $\quad-\begin{array}{lllllll} & 1 & 2 & 1 & - & 4\end{array}$ Bakery

37 Groundnut business

38 Animal grass $\quad-\quad-\quad-\quad \begin{array}{lllll} & - & - & 1\end{array}$ business

39 Electrical business $-1 \quad-\quad-\quad \begin{array}{llll}1 & - & 1\end{array}$

40 Print and Xerox $1 \quad 1 \quad-\begin{array}{lllll}1 & - & - & 2\end{array}$ shop/Stationary

41 Beauty parlour $\quad \begin{array}{llllllll}1 & 2 & - & - & - & 3\end{array}$

42 Lime business $\quad-\quad \begin{array}{llllll} & - & - & - & 1\end{array}$

43 Chips making $\quad-\begin{array}{llllll} & 1 & - & - & - & 1\end{array}$

44 Panipuri business $-\quad-\quad 2 \quad-\quad-\quad 2$

45 Pooja items $1 \quad-\begin{array}{lllll}2 & - & - & 3\end{array}$

46 Wood crafts shop $\quad-\quad-\quad \begin{array}{lllll} & - & - & 1\end{array}$ 


\begin{tabular}{|c|c|c|c|c|c|c|c|}
\hline 47 & Soft drink shop & 1 & - & 1 & - & - & 2 \\
\hline 48 & Threads business & 2 & - & - & - & - & 2 \\
\hline 49 & Auto & - & - & 1 & - & - & 1 \\
\hline 50 & Flower business & 2 & - & 1 & - & - & 3 \\
\hline 51 & Photo studio & 1 & - & - & - & - & 1 \\
\hline 52 & Carpenter & - & 1 & - & - & - & 1 \\
\hline 53 & Doll making & - & 1 & - & - & - & 1 \\
\hline 54 & Noodles shop & - & 1 & 2 & - & - & 3 \\
\hline 55 & Season business & 1 & - & - & - & - & 1 \\
\hline 56 & Tea house & 1 & 1 & 1 & - & - & 3 \\
\hline 57 & Cotton wicks & 1 & - & - & - & - & 1 \\
\hline 58 & Pan shop & 1 & 1 & - & - & - & 2 \\
\hline 59 & Coconut shop & 1 & - & - & - & - & 1 \\
\hline 60 & Chappal shop & 1 & - & - & - & - & 1 \\
\hline 61 & Goatery/Shepary & 3 & - & - & - & - & 3 \\
\hline 62 & Weaving & - & 2 & 2 & - & - & 4 \\
\hline 63 & Bangle shop & 2 & 2 & 2 & - & - & 6 \\
\hline & Total & 77 & 95 & 87 & 25 & 2 & 286 \\
\hline & $536.108^{* *}$ & \multicolumn{6}{|c|}{.00} \\
\hline
\end{tabular}

** : Significant at 0.01 level of probability.

\section{CONCLUSION}

SHG is a novel and innovative organizational setup in India for women upliftment and welfare. The role played by SHGs in the field of empowering women, particularly in the rural areas is being recognized. In India, there is a silent revolution made by the SHGs to uplift the economic condition and empowerment of women. The SHGs are characterized in empowerment of women through focusing attention on women below the poverty line to provide self-employment and establishing different cottage enterprises by imparting training in different activities and improving the available local skills, improving the status of women in the family as well as in the society. It offers not only economic opportunities but also a change to learn new skills, make wider social contacts and experience. It creates an environment through positive economic and social policies for full development of women to enable them to realize their full potential. Thus the SHGs certainly play an important role in women empowerment. The findings of the study revealed that majority of women were found to be involved in traditional activities as they were less risky. Hence, training on viable and challenging enterprises should be given to these groups thus decreasing competition in the market.

\section{REFERENCES}

Bhagyasree, P. 2014. A study on capacity building and empowerment of self-help groups in Thane district of Maharashtra. M.Sc. (Ag.) Thesis. Acharya N G Ranga Agricultural University, Hydearabad, India.

Borah, A. 2014. Women empowerment through self-help groups-A case study of Barhampur development block in Nagaon district of Assam. Journal of Economics and Finance, 4(3): 56-62.

Hemalatha. 2012. Skill development of women micro entrepreneurs-A study among self-help group members in Kerala. Asia Pacific Journal of Marketing $\mathcal{E}$ Management Review, 1(3): 113-120.

Soni, A. 2015. Role of self-help groups in women entrepreneurship development: A case study of Jalandhar district, Punjab. Advances in Economics and Business Management, 2(15): 1484-1488.

Sowjanya. 2007. A comparative analysis of successful and unsuccessful self-help groups in Gadag district of Karnataka. M.Sc. (Ag.) Thesis (Unpublished). University of Agricultural Science, Dharwad, India.

Vijayabharathi, G. and Masthani, S. 2014. Self-help groups an instrument for the development of women entrepreneurship. International Journal of Management $\mathcal{E}$ Business Studies, 4(2): 48-53. 